This is the accepted manuscript of the article, which has been published in Global Networks. https://doi.org/10.1111/glob.12227

\title{
Post-socialist legacy in transnational families: Russian and Polish women in Finland
}

\author{
Authors: TATIANA TIAYNEN-QADIR, ANNA MATYSKA
}

\section{Introduction}

Studies on transnational families have grown into a substantial area of research with specific theoretical frameworks and insights on varying forms of transnational care, family bonding and flows of remittances (Bryceson and Vuorela 2002; Skrbiš 2008; Zontini 2011; Kilkey and Merla 2014; Baldassar and Merla 2014; Baldassar et al. 2016; Horn 2017; Butt 2018). In particular, there is a growing body of literature that addresses family ties of migrants from Eastern Europe (see for instance Burrell 2008; Ducu 2014; Nedelcu and Wyss 2016; Nesteruk and Marks 2009; Ryan 2011, Bojarczuk and Mühlau 2018; Ducu, Nedelcu and Telegdi-Csetri 2018). Although these studies have greatly enhanced our empirical understanding of migration, they scarcely engage with postsocialist anthropology research, often operating with concepts and epistemologies from transnational studies shaped within the Anglo-American academic discourse, and with a clear empirical focus on postcoloniality. On the other side, many studies on postsocialism overlook transnational linkages and methodological nationalism continues to shape gender and family research on postsocialist Europe. Thus, we still know little about how lived experiences of postsocialism shape transnational family practices of Eastern European migrants today.

This article aims at bridging the analytical gap between transnational anthropology and anthropology of postsocialism by illustrating how both perspectives can be combined in order to attain more nuanced as well as culturally and historically grounded accounts of transnational families. Thus, the purpose of this article is to explore whether and how postsocialist gender and family practices inform women's transnational family living in-between Poland, Russia, and 
Finland as a hosting country. Our anthropological interest is in the processual, day-to-day construction of transnational families, as well as women's creative agency in making their families (Carsten 2004; Jallinoja and Widmer 2011). Such in-depth insights into how family is actually lived by women are possible due to our long-term immersion and multi-sited ethnography in and between these three national sites.

The article responds to calls to incorporate transnationalism into studies of postsocialism (Verdery 1998; Huttunen 2009; Cervinkova, Buchowski and Uherek 2015) on the one hand, and contributes to emerging research that offers accounts on how postsocialist gender and family contexts affect transnational migration (Solari 2010; Deneva 2012; Keough 2006; King and Vullnetari 2009; Vullnetari and King 2014; Bloch 2017; Author B; Tiaynen 2013) on the other. We argue that this bridging yields new understandings of varying historical legacies of intimate transnationalism and enables taking Eastern Europe and the associated category of postsocialism out of the "Cold War ghetto" of area studies (Cheri and Verdery 2009, see also Author B).

We argue that gender regimes and family practices of postsocialist Russia and Poland significantly shape women's transnational family living between these two sites and Finland. We point to three interrelated aspects of the postsocialist legacy: 1) an inclusive understanding and practice of family, which involves interaction of immediate and extended family configurations, 2) intergenerational solidarity among women, and 3) feminine subjectivity built on the socialist ideal of a working mother. We indicate that Finland as a destination country, with its welfare state policies encouraging women's labour market participation (Meagher and Szebehely 2012), provides important continuities for these gendered postsocialist practices to evolve transnationally.

The article unfolds as follows. In the next two sections, we provide a background of gendered and family practices during socialism and postsocialism, conceptualize transnational families and contextualize conditions of transnational mobility between Russia, Poland and Finland. These sections are followed by the methodology section, in which we introduce our specific empirical case studies. We illustrate our argument in the two subsequent empirical sections through the life stories of two women, Vesta from Russia and Aleksandra from Poland. Their life stories and 
narratives vigorously encapsulate key legacies of postsocialism in transnational family living, and how these legacies are very much alive in the women's self-identifications and practices as transnational grandmothers, transnational daughters and immigrant mothers. The concluding discussion section summarizes the argument and discusses our reflections on combining transnational and postsocialist perspectives.

\section{Gendered family lives in socialist and postsocialist Poland and Russia}

Socialism was introduced as a state policy in Soviet Russia in the aftermath of the Russian Revolution of 1917, and in Poland after the end of the Second World War in 1945. Drawing on Marxist ideology, it was designed as an egalitarian system in which the state - through the Communist party — was to carry out redistributive and caring functions, thereby diminishing the moral and material significance of the family (Verdery 1996: 61-79). However, against state ideology and the economy of shortages, family-centred interpersonal relations became the locus of everyday practical and emotional life (Blagojevic 1994; Nowak 1979; Simic 1983; Wedel 1986; Kravchenko, Gradskova and Carlbäck 2012). Mutual aid in families constituted a buffer

against the permanent scarcity of resources and provided an individual with a fundamental sense of security. Although a married couple was a culturally desired cornerstone of socialist family life (Robila 2004), it was heavily embedded in larger kinship structures. In practice, there were also many single mothers after WWII who managed their everyday survival and child care by relying on intergenerational women's networks (Tiaynen 2013).

As intimate units, these extended family configurations emerged as 'real' in contrast to communist ideology and power, which by the time of late socialism became increasingly conceived of as something artificial, imposed and illusory. For instance, Buchowski (1996) conceptualizes extended, cross-cutting family units as central components of civic society in communist Poland and the basis of the opposition between 'us' - the people - and 'them' - the communist government. The practical importance of family during socialism was supported normatively by traditional family culture of Orthodox Christianity in Russia, and Catholicism in Poland. Although religion was officially seen as 'backwardness' and 'vestige of the past' by communist ideology, Orthodox family values continued to have discursive power in the Soviet 
Union, albeit in secularized form. This was the case even more in Poland, where the Catholic Church openly opposed the communist regime.

Aiming at egalitarianism, but falling radically short, socialism introduced a gender regime in which women's emancipation blended with traditional, gendered division of labour. Socialism insisted on women's 'obligatory' right to work as a way of achieving 'women's equality', but at the same time upheld the notion of motherhood as a natural destiny and civic duty of women (Ashwin 2000; Fidelis 2010; Zdravomyslova, Rotkirch and Temkina, 2009, Szlagowska 2016). An ideal of a socialist woman who fulfils herself both as a homemaker-a mother and wife - and as an independent worker had a significant influence upon family life.

First, family was envisioned as primarily a woman's domain, whereby women were faced with a 'double' or even 'triple' burden of domestic work, wage work and mothering. Secondly, the early age of retirement combined with kinship expectations of intergenerational care allowed older female family members, usually the grandmothers (babushka in Russian, babcia in Polish), to actively support their adult children through unpaid domestic work and childrearing (Verdery 1996, 65; Ries 1997; Novikova 2005; see also Tiaynen 2013). Women's intergenerational solidarity strengthened the feminization of family space and enabled younger women's paid employment.

Postsocialist capitalist transformation brought new socioeconomic changes into family living, but it did not fully wipe out the socialist legacy. Scholars use the term postsocialism to denote the continuity with the past in the understandings and practices of the present (Burawoy and Verdery 1999; Gal and Kligman 2000; Hann 2002; Verdery 1996; Jansen 2015). This is especially the case with regard to those people, who had lived much of their adult lives during socialism. Of course, Russia and Poland are facing multiplication of family forms similarly to other Eastern European countries: an increase in cohabitation, single-parent households, informal marriages and re-constituted, post-divorce families (Robila 2004; Slany 2002; Zdravomyslova et al 2009). 
Simultaneously, however, certain socialist patterns of family living persist. Extended families help to deal with uncertainties of capitalist economy and unemployment (Robila 2004; Stanisz 2013; Bloch 2017). At the same time, despite shifting norms and expectations, women remain the emotional and practical cornerstone of family living, combining both productive and reproductive roles (Ashwin 2000; Gal and Kligman 2000; Kravchenko et al. 2012). Presently, social movements and gender studies inspired by the liberal idea of womanhood coincide with public discourses, which often reify the naturalization of gender roles (Kay 2007: 3-5; Uspenskaya and Borodin 2004, Graff 2014). Catholic and Orthodox churches are now resurging in Polish and Russian public domains respectively with their support for traditional gender culture, rather as an ally than enemy of the state.

\section{Transnational mobilities and transnational families}

Transnational mobilities from Eastern Europe add up to the increased diversity of postsocialist family forms through triggering the emergence of transnational families. We understand transnational families as flexible and gendered communities which "live some or most of the times separated from each other, yet hold and create something that can be seen as a feeling of collective welfare and unity, namely 'familyhood', even across national borders" (Bryceson and Vuorela 2002,3). Transnational families have become a subject of theorizing in transnational anthropology that scrutinizes phenomena transcending national borders and nation-state imaginaries (Appadurai 1996; Vertovec 2009; Hannerz 1996, 2010; Salazar 2017). By their very existence, transnational families challenge methodological nationalism; by their nature, they represent an elusive phenomenon, capable of unending mutation and reconstitution over time (Bryceson and Vuorela 2002). Recent research illustrates that transnational families often have to deal with the pain of physical separation. Gendered inequalities and women's burden of care may be enhanced amid transnational mobility and globalization (Parreñas 2001; Fan and Parreñas 2018; Keough 2006).

However, transnational family space is also a site of mutual care and support for its members, in which gendered practices and identifications may be challenged and renegotiated (Bryceson and Vuorela 2002; Solari 2010; Zontini 2011). Affordable travelling and new telecommunication 
technologies facilitate emotional proximity and family bonding (Vertovec 2009; Baldassar and Merla 2014; Baldassar et al 2016). Extended transnational families become emotionally and practically immediate, even against the odds of separation, especially due to women's agency in making their families across borders (Author B; Tiaynen-Qadir 2016). Matrimonial and parental ties in immediate transnational families are significant, but they immerse into extended families in the course of everyday life in accordance with the logic of postsocialist family living.

Transnational studies illustrate the importance of institutional context, welfare and gender regimes, state policies and international regulations for transnational family arrangements (Skrbiš 2008; Kilkey and Merla 2014; Author B; Tiaynen-Qadir 2016). The Cold War policies of the Eastern bloc limited transnational mobility between the East and the West. Mobility of Soviet people was highly restricted and primarily allowed only within the Eastern bloc (Tiaynen 2013). The Polish communist government allowed more lenient emigration policies, arguably due to the strong diasporic tradition of the Polish nation. Nevertheless, Poles had limited access to passports and were allowed for exit only selectively (Author B). The collapse of the Soviet Union gave a significant boost to Russian and Polish transnational mobility and, accordingly, to transnational families. Poles in particular gained freedom to move without a passport after joining the European Union in 2004, whereas Russian citizens still need a visa to enter the European Union. Nevertheless, many Russians and Poles found a footing in Finland, which had maintained a position of political neutrality through the Cold War era (although economically belonging to the capitalist West) and had joined the EU only in 1995.

Polish and Russian mobility to Finland is characterized by historical interconnectedness. Poland, Russia and Finland are located in geographical proximity to each other. Finland shares a border with Russia by land and by the Baltic Sea with Poland, which in turn neighbours Russia by land. The longest border between Russia and EU is the border between Finland and the Republic of Karelia (hereafter, Russian Karelia). In the $19^{\text {th }}$ century, Poland and Finland were part of the Tsarist Russian Empire, thus together constituting a common polity. Much of Russian and Polish mobility to Finland related to the movement of military and administrative personnel as well as traders within the Empire at that time. With the end of the Tsarist Empire in 1917, many people were repatriated, and significant mobility started only after the Soviet Union collapse, when 
Eastern bloc borders opened. Thus, Finland's location shifted from being on the geopolitical border of the Iron Curtain to becoming the border of the European Union with Russia. Polish postsocialist mobility to Finland — particularly post-EU accession — took on labour and familyrelated characters, for both temporary and permanent stay.

Nowadays, there are around 6,000 Poles in Finland. Russians, apart from moving for labour and family reunification, also moved as 'Ingrian returnees' enabled by the repatriation program initiated by Finnish President Mauno Koivisto in the 1990s. As a result, more than 30,000 Ingrian Russian-speakers came to Finland, contributing to the emergence of Russian-speakers as the largest migrant minority in contemporary Finland, amounting to approximately 75,000 (in a total population of 5.5 million).

With these changes in the institutional and border context, Russian-Finnish and Polish-Finnish spaces have grown into lively arenas of transnational family interaction. For instance, the geographical proximity between Russian Karelia and Finland, legal character of migration, and affordability and availability of transportation, facilitate frequent commuting of family members in-between these two sites. Similarly, cheap air flights and the increased possibilities of travelling from Poland to Finland by car or ferry increased the frequency and length of family visits. Thus, the "increased interconnectedness" of the world (Hannerz 1996) in these formerly politically divided spaces further encourages to rethink families in a transnational mode.

\section{Ethnography of family making}

Empirically, this article draws on two sets of data: multi-sited ethnography (Marcus 1995) of transnational family life conducted by Tatiana Tiaynen-Qadir between Russian Karelia (The Republic of Karelia) and Finland, and Anna Matyska between Poland and Finland. Both studies include series of ethnographic interviews, with 31 Russian grandmothers and with 84 different family members (particularly adult migrants, their children, as well as seven elderly parents in Poland) making up Polish forty transnational families. The core of both fieldworks was conducted in 2006-2009, but we have continued our involvement in the field and acquaintance with interlocutors to the present. Tiaynen-Qadir also undertook her cross-border ethnography in 
mini-buses that take passengers between Russian Karelia and Finland, which enabled observing the scale and intensity of family relations in this transnational context. Overall, our findings need to be seen as the result of long-term immersion and ethnographic engagement: our fieldwork research was a 'way of being' or 'matter of living' (Cerwonka and Malkki 2007: 178).

Our access to the field was facilitated by our "insider" status, being researchers who study our fellow compatriots in their native languages. Amit Vered argues that 'it is becoming a virtual truism to note that the distinction between 'home' and 'away' has become blurred by the transnational contexts in which anthropologists and their ethnographic subjects now move' (Vered 2000: 15). We are researchers on the move, and transnational family members, circulating between our respective homes of origin and Finland as our new 'home'. On the one hand, living physically in-between Russia and Finland, and Poland and Finland, allowed us an emic perspective into transnational family processes. On the other hand, being situated inbetween various academic traditions enabled us to develop analytical distance towards our data and towards existing research produced in different contexts. Such negotiation between theory and practice, intrinsic to our fieldwork research, was complemented by our joint analytical efforts in re-reading and scrutinizing our data.

In the following sections, we discuss our findings. We introduce stories of Vesta and Aleksandra (both names are pseudonyms), women of similar age but different positions in transnational family space. We have chosen to focus on Aleksandra's and Vesta's stories because their lives embody what we construe as a postsocialist legacy in transnational family life. Aleksandra represents the cultural ideal of Polish woman shaped by a socialist past. Similar to other Polish women in Finland, she strives to be a devoted mother, wife, daughter and a working woman. Aleksandra's case accentuates the gendered and intergenerational solidarity in transnational families. In the Russian case, Vesta is one of Tiaynen-Qadir's key interlocutors; intense daily interaction with her went beyond seventeen recorded interviews. Vesta is the epitome of a Russian babushka (Krasnova 2005; Novikova 2005; Utrata 2015; Tiaynen 2013; Tiaynen-Qadir 2016), a caring grandmother of her extended family dispersed across the Russian-Finnish border. Yet, similar to other interlocutors in Tiaynen-Qadir's research, Vesta cherishes her working life and identity. Both cases have common moral and practical roots in the socialist past and 
postsocialist transnational present. The empirical sections follow the ethnographic style, and are therefore written from the perspective of interaction between the researcher and the interlocutor.

\section{Vesta's life story: Russia and Finland}

Vesta's and my conversations were never structured, and most topics occurred spontaneously as we talked in a kitchen at my place or hers in Petrozavodsk, the administrative capital of Russian Karelia. The fact that the kitchen was the most common place for our talks over a cup of tea is no accident. The kitchen grew into a 'sacred' place of Soviet everyday life, no matter how tiny Soviet kitchens would be (Ries 1997). Apart from family gatherings and gossiping, it was a place where people could talk out their minds, even when it would go against the official ideology. With this significant cultural baggage, the importance of the kitchen in having our informal and trusted conversations (beseda in Russian) could hardly be overestimated.

Vesta's narratives are notable in disclosing two types of 'love' that nourish her sense of identification and selfhood till now. First: love for her family, her parents and especially her daughters, the 'grain' of Vesta's life, whom she 'loves so much'. Second: love for her work and the entire social world it implies. In this affection, she shares an identity of a working mother with many other women with socialist background. However, the working mother ideal was not only a cultural, gendered script that socialist women enacted and blindly followed in their lives. It was filled with life, purpose, meaning, and 'creative agency' (Reid 2014). Such agency was 'sometimes in line with the announced goals of the state, sometimes in spite of them, and sometimes relating to them in ways that did not fit either-or dichotomies' (Yurchak 2006: 9). Vesta's case reveals this type of agency.

Vesta was born in 1943 to a rural family in north-western Russia. She recollects her parents and her childhood years fondly, talking about her mother who was 'skilful in baking pies and bread' and her father, a 'fisherman who used to give a lot of fish to sel'bam [the state farm in the village]'. Vesta refers to her parents as 'our' parents, always keeping in mind her brother and 
sisters, with whom she regularly keeps in touch. This plural noun gave a sense that she included them in her family scape even now.

After her parents' death, Vesta moved to her elder sister who lived in an urban area. She was looked after by her sister, but also helped her with a newly born baby. By taking care of her niece, Vesta became part of extended family support and women's intergenerational care at an early stage of her life. She remained with her sister until she herself got married in her early twenties. After that, Vesta became immersed in her immediate family, which included her husband and two daughters:

Man is a head, and woman is a neck. I could anticipate his [husband's] steps, and then I could act accordingly ... When the working week ended, I usually took his hand and told him: Oi, Valentin, we are going to go to bania [sauna] today! Although, we were actually taking a bath at home. But his soul melted ... We would bathe our children, then they would go to sleep, and we also took a bath. Then we would be sitting together, and he would drink a couple or three glasses. We were working together. So, we knew the same people. There was always a common topic for conversation.

This quote captures emotions, intimacy and affection of nuclear family bonding and partnership between spouses. It can be seen as a paradigmatic example of traditional gendered relations in Soviet Russia (Ashwin 2000; Zdravomyslova et al 2009). Yet, it also illustrates a subtle authority and micro-powers that women could exercise in a family domain in Russia and other Eastern European contexts (Ries 1997; Simic 1983; Blagojevic 1994). Vesta always lovingly recollected her husband, even speaking warmly and humorously of his flaws, and stressing that his "true beauty came from inside." She kept his photo, carefully covered by an icon of the Virgin in her kitchen windowsill.

Vesta had "a great desire to learn," and she was proud to rise from being a housepainter to a programmer in a laboratory in a military institute, where she worked with her husband. For a Soviet woman (and man), the world of paid work had tremendous social, economic, and political functions, penetrating almost every aspect of social existence (Lonkila and Salmi 2005: 681). 
Social services and benefits (which Vesta and her husband enjoyed) - such as subsidized food, health and public child care, housing, leisure and tourism - were mediated through the working collective. This was particularly the case with military-related work places. In addition to her work duties, Vesta was active in her workplace council. For Vesta, the workplace was also where she met her husband, developed friendships, had fun at collective gatherings, as well as could perform her femininity and "show off" wearing nice dresses and having a special hairstyle:

Sometimes I long so much for my work... When I worked, and my husband earned well, I used to change dresses every week. I often went to a hairdresser to make a special hairstyle. Here [showing me a picture] I am wearing a white fur hut. It is a demonstration [October Revolution Day]. We all participated in demonstrations, and I really liked it.

Commemoration and celebration of 'the October Socialist Revolution' was one of the major Soviet holidays, featuring fireworks, speeches, as well as workforce and military parades often referred to as demonstrations (demonstratsii). An ideologically driven event, for Vesta it was also a moment of personal joy and an opportunity to bond with her colleagues. For her and many other Soviet women and men, the work collective generated a kind of sociality (Yurchak 2006) that united them in that particular social reality they all were part of. This was what Vesta longed for in her postsocialist life, although at this stage she was more aware of the ideological nature of many aspects of that life.

Vesta became a widow in her late forties. By that time, she had already become a grandmother, which was a turning point in her life. Vesta's daughters had moved to Petrozavodsk, and she acted as a translocal grandmother at a distance. At the same time, she started dating a man ten years younger than her who remained her partner for ten years. Vesta's sense and understanding of family seemed to grow larger, embracing her daughters' families, including her four grandchildren but also her partner had a special place in her family space. When Vesta's daughters moved to Finland with their families, her sense of family and intimacy linked to it did not change, but the forms of maintaining family had to: 
My motto is my family. First, my elder daughter came here [Petrozavodsk] to study, then the younger one followed her. My husband died. I love my children so much, I moved here because of the children. In my city, I lived around 50 years ... I understood that a life without my children is not for me. They are the essence of my life. As fate has willed, they have moved to Finland. So, I am alone here, but I visit them and they visit me.

Vesta can be seen as a transnationally mobile grandmother (Plaza 2000; Deneva 2012; Nedelcu 2017; Tiaynen-Qadir 2016) who commutes regularly between Russian Karelia and Finland. When Vesta goes to Finland she stays primarily with her younger daughter, whose two children need more practical care from a babushka than her other two grown-up grandsons, the sons of her elder daughter. All Vesta's grandchildren are enrolled in early childhood and school public institutions. Yet the babushka's help is seen as an asset in arranging busy family schedules, including children's hobbies. In my conversation with Vesta, as well my other interlocutors and their adult children, it became evident that the babushka's help is indispensable as a complement to public child care (see also Bloch 2017; Utrata 2015), something unique and familial associated with love and emotional comfort that the formal care arrangements cannot replace. For instance, Vesta tried when possible to collect her grandchild earlier from day care. She made special efforts to pick her older grandson up from school. Not that it was practically necessary, but because it 'made them happy'. Vesta also saw those comforting practicalities as emotionally rewarding for her as she 'could spend time with the kids and be joyful as a child herself'.

The Finnish visa regime with the Russian Federation allows Vesta (as all Russian citizens) to apply for a visa for a maximum of ninety days within half a year. When staying in Finland, Vesta is irrevocably involved in her daughters' family routines:

During this half year I was in Finland three times, so five to six times per year, spending one month every time. At Julia's place I am walking with the kids, twice before dinner and once after dinner. I am also playing with them at home. Julia is now cooking by herself and I am mostly with the children... With Mish a [the elder grandson] we are walking long distances. When I am at my older daughter's place I am cooking, watching TV, reading, and cleaning the house. They 
come home, and we eat supper together. We go shopping often and take a walk before we go to bed.

Vesta's identity of a working mother also shapes her grandmothering practices. Similar to many of my interlocutors, two pillars of the Soviet working mother contract - work and motherhood (Zdravomyslova et al., 2009; Ashwin 2000) — are decisive criteria and values against which she evaluates the success of her own life, and the lives of her daughters. In Russia, she was active in her grandmothering in order to enable her daughters to study and work. In Finland, she enables her daughters to go to Finnish language courses to facilitate their integration into Finnish society to become successful working mothers.

In this way, the Finnish gender context provides more continuity than it seems at first glance. With all the differences in ideological and political framing, work and motherhood have also been both deliberate choices and necessities in everyday lives of Finnish women (Lähteenmäki 1999: 54). The housewife idea, which used to be popular among middle-class Finnish women in the first half of the twentieth century, was never realized in Finland simply because Finland was considered too much 'a poor country' to keep its mothers at home (Lähteenmäki 1999: 48). Thus, the receiving context of Finland with similar ideas of women's work and maternity duties makes it easier for the 'working mother' contract to be reproduced in women's transnational mobility (see also Pöllänen 2013). Vesta's case illustrates this continuity with postsocialist legacy in the Russia-Finland transnational context for grandmothers.

Vesta's case also shows how mutual reciprocity and women's intergenerational networks are involved in family living. She liked mentioning that all the clothes she has got and her 'good' life is due to her daughters' care. The communal services for Vesta's apartment in Petrozavodsk are paid for by her younger daughter. Her daughters take the initiative in making regular calls to their mother when Vesta stays in Petrozavodsk. In these conversations, the most mundane details of family life are discussed: how the school day of one grandson was, how the youngest one was doing in the day care, how it was going between her eldest grandson and his girlfriend. These family talks, enabled by new telecommunication technologies, serve as "a kind of social glue connecting families" (Vertovec 2009: 56; Baldassar et al. 2016; Nedelcu and Wyss 2016; 
Nedelcu 2017). They are vital for family routinization, maintaining their transnational family as an imagined and real community (Bryceson and Vuorela 2002). Thus, Vesta continues to be virtually involved in transnational family routine through telephone calls that her daughters regularly make:

My daughters call me every day. They also take me as a friend. They live there, but they are missing me. They call me and tell me everything ... I can always advise them what to do and support ... I don't know even how to use the phone properly. They call me, and I just press the button ...

There was also another important space of family making in her apartment in Petrozavodsk, a home altar (typical of Orthodox homes), where her entire transnational family was brought under the protection and blessings of Trinitarian God, the Mother of God, and saints in Vesta's daily prayers (Tiaynen 2013). Vesta mentioned that she (re)discovered Orthodox faith in the 1990s, when resurged religion socially and politically. Thus, the way family is now lived, understood and imagined by Vesta transgresses the borders of a nuclear family and state borders, including her multi-sited living 'here' and 'there'. This extended family scape includes those who passed away_-Vesta's parents and husband — but somehow continue to invest in the feeling of familyhood through Vesta's narratives and recollections. Vesta's case illustrates well how transnationalism affects people who do not officially migrate, but whose lives are considerably affected by others involved in migration (Vertovec 2009).

\section{Aleksandra's life story: Finland and Poland}

"I told myself that I'm not a housewife (kura domowa in Polish, literally a 'domestic hen'): I wasn't a housewife, I'm not a housewife and I won't be a housewife," Aleksandra—a small business owner - told me emphatically, rushing between the dining room and kitchen of her Finnish house. I have met Aleksandra, as many other of my interlocutors, at a Polish mass in Turku, a coastal city in Western Finland. She always attended the Church with her elderly mother and 10-year old son. Two weeks before Christmas she invited me for dinner. As usual, she was preparing all the food by herself. Her Finnish husband sat at the table, staying silent 
most of the time, while her mother watched Polish Church mass on TV. She had early stage Alzheimer's and participated in the conversation only occasionally. Aleksandra talked mostly standing, overseeing things in the kitchen. Only after dinner we had a chance to talk more peacefully. I realized that constant busyness, in and outside of home, is a central feature of her life and a necessary precondition for fulfilling her self-ideal as a caring family woman who succeeds as a working woman as well. She embodied what I would regard as a socialist version of a 'Polish Mother' (Matka Polka) ideal, enacting it in her national and transnational family life.

The ideal of a 'Polish Mother' dates back to Poland's statelessness in the nineteenth century, when Polish women through devoted and agentic motherhood, strengthened by the Catholic belief, were imagined as the guardians of Polish national continuity. The socialist state drew on this ideal to promote the vision of a woman who, while devoting herself to the family, nourished the socialist values of economic independence and professional activism (Szlagowska 2016). Accordingly, by using the term kura domowa in reference to her potential role as a housewife (see also Ciesek 2017: 20), Aleksandra discursively denigrated woman's boundedness to the domestic sphere only and lack of aspirations reaching beyond it. By saying she had "never been" kura domowa, she was not one, and she would never be one, she also created a temporal connection between her past, present and future self, which has been historically embedded in the socialist and postsocialist trajectory, and spatially rooted in Poland and Finland.

I have never asked Aleksandra about her working life, partially because Aleksandra spontaneously and in detail included it into her life story. The first clue to the transnational ties between Aleksandra's past and present working self, I discover at Aleksandra's fiftieth birthday party, which I attended few weeks earlier. Aleksandra circulated a scrap book filled with photos among the guests. It was a self-made narrative highlighting the key moments of her life. One of the photos caught my attention: it portrayed Aleksandra in a white gown surrounded by colleagues at the beautician parlour in Poland. The photo gave the sense of work as a space of fulfilment and social belonging, which Aleksandra confirmed when she told me her life story.

Aleksandra was born in a village in Southern Poland in the 1950s. Her parents were small-time farmers. Aleksandra was the last of three siblings to move out from home. She attended high- 
school in a nearby town, benefiting both from her parents' financial support and socialist policies promoting industrialization and emancipation of the "rural masses". Young rural people were encouraged to migrate to the city to join the ranks of urban labour force and help build the socialist economy (Mędrzecki 2003: 152-160). Aleksandra had three long-term jobs in Poland: she was the head of the provision unit in a prison, a travel agent, and a beautician. Even though it was the job at the beauty parlour that gave her practical skills to open up her own business in Finland, it was the first two jobs that she spontaneously recalled with particular detail, arguably because of the prestige and benefits they yielded during socialism.

My job in prison was of course arranged (zalatwiona) for me by my brother-in-law, because this is the way things were done back then. My salary was high: 3,500 zlotych. Because we were part of the State of Justice Department, we had discounts for train and plane tickets, and all of these things ... I left it when I discovered I can work at Orbis, the famous Orbisie [the biggest travel agency in Poland during socialism]. Orbis was a paradise, a big world! ... But one worked hard. I had 15 minutes break. I organized hotels and transportation. In the 1970s, Polish people travelled a lot to Bulgaria and other countries of the bloc.

In the 1980s, Aleksandra started working in a beauty parlour, a job she thoroughly enjoyed. During this time, she also gave birth to her first child, a daughter named Joanna. Joanna's father never took interest in their daughter's life, making Aleksandra her prime material and emotional caregiver, supported by the grandparents. Aleksandra, however, wanted to have a husband with whom she could share her domestic life and who would be a good father to her daughter-not unlike Vesta in the previous section. At the beginning of the 1990s, Aleksandra met Mikko, a Finn working in Poland. They fell in love but as Aleksandra told me, it was her daughter who made the decision for her when one day she grabbed Mikko's hand and said 'He is my dad', an image that emphasizes to what extent Aleksandra's desire for a husband was linked to her desire to be a good mother. The meeting brought a fundamental turn (although not a discontinuity) in her life, as in 1993 Aleksandra married Mikko and moved to Finland. In Finland she gave birth to her second child and after finishing the maternity leave, she has faced the situation which was unknown to her before: she became unemployed. 
It is common for female migrants who migrate under reunification schemes to face unemployment (Pajnik and Bajt 2010). However, the lack of job was something Aleksandra considered unacceptable. Despite coming from a relatively poor country which had barely left the socialist bloc, Aleksandra refused coming as an appendix to her husband and desired to build upon what she considered as valuable symbolic and material status that she managed to attain on her own in Poland. Socialist ideology clearly yielded emancipatory results, underlying female agency and self-constitution in migration narratives and stories (on female agency in Polish family reunifications see also Ryan 2011).

The continuity of Aleksandra's aspirations was matched by certain cultural continuity with gendered socialist traditions professed by the Finnish state. In Finland, Aleksandra started to attend Finnish language and vocational courses sponsored by the state, where she was encouraged to find work and, at some point, to open up her own business drawing on her experience from Poland. As she put it: "I got great professional consultants at the course. They told me I would make it and even estimated what would be my first salary. They really gave me a boost to do it. And helped me deal with all the paper work." Family gave her the other type of support she needed: the husband financially and her mother practically.

Aleksandra's efforts to create a family of her own and work simultaneously were practically aided by her transnational family embeddedness. After her father's death, her mother became a central node in Aleksandra's webs of extended transnational kinship, providing her with childcare at crucial stages of migration, starting from Aleksandra's first visits to Mikko in Finland. Aleksandra's mother's crucial role as a grandmother to Aleksandra's children is reflected in the language Aleksandra always used when referring to her mother, continuously interchanging 'mother' (mama) with 'grandmother' (babcia):

My mother helped me immensely. I was bringing up Joanna on my own, and when I visited Mikko for the first time in Finland the grandma (babcia) stayed with Joanna. And such grandmas do not happen often. Joanna was only 6 years old, she got sick [when I was gone], my mom was by herself in the village, and had to ask neighbours for help. So, she took this responsibility upon herself. 
The help continued when Aleksandra moved to Finland and gave birth to her son who, due to illnesses, required special care. Similar to Vesta, Aleksandra's mother acted as a transnationally mobile grandmother, commuting between Poland and Finland to take care of her grandson. In the meantime, Aleksandra attended courses, studied Finnish and worked. Thus, her mother's transnational engagement helped Aleksandra to integrate into the Finnish labour market, learn the language and establish an independent business. As a result of her grandparenting efforts, Aleksandra's mother told me of her grandson: "He is mine. I was practically like a mother to him", evoking her role as an 'othermother' in the transnational family (Bloch 2017).

The help provided by Aleksandra's mother was not indispensable as Aleksandra could draw on the public childcare system for support. This contrasts in particular with the study of Polish migrant mothers in Ireland, for whom transnational grandparental support is a dire necessity considering that Irish formal childcare is the most expensive in Europe, with shortage of facilities and poor quality of care (Bojarczuk and Mühlau 2018). For Aleksandra, as she told me, state help was an available, but secondary option. She seemed to perceive her mothers' help as a naturalized way of care which did not contradict but rather enhanced her own ability to be a good mother, who works while not neglecting the familial caring needs of her child. Eventually, Aleksandra and her husband, despite the reluctance of Finnish authorities, succeeded to arrange for Aleksandra's mother to move to Finland.

At the same time, Aleksandra interpreted her mother's visits in reciprocal terms, as a mutual transnational provision of care (Baldassar and Merla 2014):

My mom became very lonely after my dad died. Very lonely. She visited us [in Finland] for the first time and she simply got used to us. I was already expecting a baby [...], then my mom came for another visit, and another. Three-months visits. And everything was great. She had strength, she was walking him outside, she was taking care of him, and she felt well, just like I felt when I came here for the first time. She felt the sense of warmth and togetherness. 
Aleksandra's narrative here shows the understanding of family as a source of warmth and strength. Living family also means providing care that can be affectively enriching. Aleksandra suggests that her mother helped her with childcare, but this also enabled her sense of family belonging and facilitated to counter her loneliness.

Aleksandra operates with the same understanding of family care when discussing the most recent years and the reversal of their roles: her mother was diagnosed with Alzheimer's disease and demanded increased on-hand care. Aleksandra mentioned the difficulties of coming to terms with her mother's situation: her wonderings at nights and the constant need to watch over her. But in the end, she said with affection, these are 'small things':

I love my mom so much. She is so difficult. She is not even aware of that. But there are no more such giving people as my mom, who give all their heart, for real. We are not able to do it, maybe me, in a way that she is with us. When she gets up at night, I check what she is up to: she pours water from one cup to another and turns things on and off. Continuously something, I think I will go crazy, but you know these are small things.

I discussed with Aleksandra the institutional care of elderly people, given its popularity in Finland. Aleksandra did not consider placing her mother at a nursing home. However, because she did not intend to resign from work either, she drew on the state assistance by having a nurse who would come for few hours daily to check on her mother. As her mother missed Poland, Aleksandra and her mother also travelled to Poland together at least once per year. During the visit, on-hand care was provided by Aleksandra's sister and Aleksandra's best friend, who was 'like a daughter' to her mother. Thus, gendered transnational family making also continued into the later stages of family life cycle (Baldassar et al. 2007) and was only partially complemented by an institution.

The Catholic Church, in which care for ageing parents is a key moral obligation, has been an important source of moral support for Aleksandra's caring efforts. Among her fellow parishioners in Finland, mostly other immigrant Poles, she found understanding or even admiration that I got to see first-hand as I belonged to the same community. Aleksandra quoted 
with pride one of the parishioners who told her: "Remember Aleksandra, your mom's Alzheimer and you taking care of her-these things happen only to strong people." This appreciation seemed to resonate with Aleksandra's self-perception as a woman who manages in all spheres of life and derives from it a moral strength, but also confirmed how Polish Catholicism affected socialist subjectivity of emancipation (Szlagowska 2016), and consequently underpinned Polish national and transnational family making.

\section{Discussion}

Transnational families live in the present but are shaped by and interact with past legacies in significant ways. The collapse of the Eastern bloc marked the failure of the socialist state and wiped out many of the socialist welfare structures and ideologies. Yet, the past continues to be made and remade in people's everyday lives as they face the changing realities of the present. Transnational families across Poland, Russia and Finland are predominantly the result of postsocialist migration waves. However, socialist legacies inform their living, successes and challenges.

We have identified three key aspects of postsocialism, which shape transnational family living in gendered ways, and have illustrated them by focusing on the stories of Vesta and Aleksandra.

First, Vesta's and Aleksandra's stories illustrate that socialist underlining of family as an immediate and extended, flexible unit continue to inform transnational family making between Finland, Russia and Poland. Both women operate with wide and inclusive definition of a family, whereby the immediate and extended family configurations co-exist and interplay across women's live spans and at a given moment of their lives. Their transnational families can be seen as a particular form of an extended family configuration, in which conjugal partnership is as important as larger kinship ties.

Second, the women's stories provide plenty of evidence of how women's intergenerational solidarity has been at work and continues to underpin transnational family living. Vesta helps her daughters with child care, but is also nurtured by them, materially and emotionally. Aleksandra's mother assisted her in child care across borders, but she also benefited from that care, and 
Aleksandra affectionately directed her care toward her ageing mother when she fell ill. It is an illumination of gendered transnational 'circulation of care', whereby a reciprocal exchange of caregiving 'binds members together in intergenerational networks of reciprocity and obligation, love and trust' (Baldassar and Merla 2014: 7)

Third, a socialist working mother continues to inform transnational family living in significant ways. Being a working mother and a wife is pertinent to both Vesta's and Aleksandra's gendered identifications. In this, the traditional gendered ideal of the mother and the wife has no contradiction with the professional woman's ideal. Yet such a combination has been mainly possible to live up to due to the women's intergenerational solidarity and public institutional support in both sending and receiving sites. The motivation behind Vesta's and Aleksandra's mother's child care efforts has been to help the daughter(s) to be successful in their lives so that they would get education or jobs in Russia or Poland and would be able to attend Finnishlanguage courses in order to integrate and gain employment in Finland. This finding resonates with several studies that point to this motivation behind transnational grandmothering of women hailing from other postsocialist countries (Solari 2010; Deneva 2012; Nesteruk and Marks 2009). Thus, we arrive at the third legacy of socialism in contemporary transnational family living that reproduces the working mother ideal as a key feature of gendered family practices.

We have discussed above that gender culture in Finland, encouraging dual roles for women, provide important continuities for these three postsocialist gendered practices to evolve in transnational families between Poland, Russia, and Finland. We argue that Finland as a destination country affords a possibility to illuminate how postsocialist transnational families are played out in the context of Nordic welfare state. Similarly to socialist countries, Finland also offers strong political and practical support for women's paid work by providing wide access to public childcare and other facilities (Meagher and Szebehely 2012). Nordic welfare states have been located, geopolitically and ideologically, between capitalism in the West and socialism in the East and came to combine both worlds (Kananen 2016, 2; Kettunen 2006, 60). This rereading of postsocialism enables our understanding of the existing socialist legacy in Finland, which facilitates the continuity of postsocialist legacy in transnational family making of Aleksandra and Vesta, as well as many other women from Poland and Russia. 
Similar to a postcolonial context, transnational family members from postsocialist sites must deal with distributional and gendered inequalities within and outside families, power relations, as well as negotiate disciplinary practices imposed on them in hosting states. Some disruptions and challenges in transnational family practices are present due to the precarious position of Eastern European migrant women in the Finnish labour market (Jokinen et al 2011), negative 'othering' of Russian-speakers (Sotkasiira 2017), as well as social services and policies that draw on normativity of the Finnish nuclear family model and parenting (Hiitola 2015). How Polish and Russian women respond to these challenges and inequalities, and what affect it has on their transnational families are a subject of ongoing and further investigation (Pöllänen 2013; Tiaynen-Qadir 2016; Author B).

In this paper, we have illustrated that combining transnational and postsocialist perspectives yields new historically and culturally situated accounts of transnational families in the making (Bryceson and Vuorela 2002). It enables tracing the cultural dynamic of gendered caring practices, women's intergenerational solidarity and multi-directional care flows in postsocialist transnational families, something that earlier studies had observed, but did not connect to the lived realities of socialism (Kilkey and Merla 2014; King and Vullnetari 2009; Nesteruk and Marks 2009; Ducu et al 2018).

However, the major benefit (and at the same time a challenge) for combining these two perspectives lies in the condition of possibility to challenge and decenter some epistemological assumptions and norms that inform many analytical accounts in both areas of research. Alongside postcolonial reading of transnationalism (Yeoh and Ramdas 2014), there is a need for including postsocialism in transnational theorizing of care. Some transnational family research draws on somewhat a-cultural instrumental theorizing on care. Such accounts tend to brush aside that care is culturally embedded and emerges as part of a larger family configuration, as well as builds on a history of reciprocity and relationships within the family.

Our empirical cases illustrate that Aleksandra and Vesta have been living and making their families in creative and agentic ways; women's companionship and mutual care are not 
necessarily weighted down by the burden of their responsibilities but may nourish a sense of security and self-worth. Both women emphasize the support and affection that institutional care cannot compensate for, and this life-felt experience of nurturing builds on their socialist and postsocialist family experiences (see also Bloch 2017). This does not, of course, mean that these relationships are not inscribed in globalized, state, and intrafamilial power relations (Fan and Parreñas 2018; Tiaynen-Qadir 2016).

At the same time, transnational anthropological perspective challenges nation-bound and essentializing accounts of gender and family in postsocialist studies. Some anthropologists of postsocialism have critiqued research that hierarchically measures postsocialist transformation against the Western norm (Hann 2002; Yurchak 2006; Chari and Verdery 2009; Reid 2014; Jansen 2015; Bloch 2017). Indeed, although postsocialist research has been vital in mapping gendered asymmetry, women's intergenerational tensions and sexist cultures in postsocialist contexts, some accounts uncritically rely on normativity of Western liberal individualism and middle-class nuclear family, as well as Western dichotomies of housewife/professional woman and liberal/traditional gendered models. As such, they are not always applicable in incorporating the complexity, historical and transnational genealogy of family, gender, and care during postsocialism.

Finally, our transnational anthropological approach also enables decentering the category of postsocialism itself, as postsocialst legacy can be found in hosting contexts in the West as the case of Finland well illustrates. Accordingly, Finland of our study could be regarded as a place of meeting of different socialist legacies, giving grounds to globalizing postsocialism as a condition extending beyond former Soviet Union and its satellites (Tulbure 2009; Atanasoski and Vora 2018). Critique of the concept of postsocialism pointed to its potential analytical exhaustion along with the demise of Soviet socialist generation (Kideckel 2014). However, based on our research we align with the proponents of postsocialist theorizing (Tulbure 2009; Atanasoski and Vora 2018), recognizing its potential in working towards social justice and equality, with the simultaneous transgression of the Soviet state socialism. Women's positive transnational life projects, ability to work and have family, and draw on the mutual support of family and the state are part of this recognition. It is also a way of criticizing the calls for dismantling the welfare 
states and austerity measures through rendering the value to postsocialist legacies in the times of not only post-Soviet but also global neoliberal transformation in which both East and West are embedded.

\section{References}

Appadurai, A. (1996) Modernity at Large: Cultural Dimensions of Globalization, Minneapolis: University of Minnesota Press.

Ashwin, S. (2000) 'Gender, state and society in Soviet and post-Soviet Russia', in S. Ashwin (ed) Gender, state and society in Soviet and post-Soviet Russia, London: Routledge.

Atanasoski, N. and V. Kalindi (2018) 'Postsocialist politics and the ends of revolution', Social Identities, 24 (2), 139-154.

Baldassar, L., C. Baldock, and R. Wilding (2007) Families caring across borders: Migration, ageing and transnational caregiving, Basingstoke: Palgrave Macmillan.

Baldassar, L. and L. Merla (2014) Transnational families, migration and the circulation of care: understanding mobility and absence in family life, London \& New York: Routledge Transnationalism Series.

Baldassar, L., M. Nidelcu, L. Merla and R. Wilding (2016) 'ICT-based co- presence in transnational families and communities: challenging the premise of face-to- face proximity in sustaining relationships`, Global Networks, 16 (2), 133-144.

Blagojevic, M. (1994) 'War and Everyday Life: Deconstruction of Self/Sacrifice', Sociology, XXXVI(4), 469-482.

Bloch, A. (2017) “'OOther Mothers,” Migration, and a Transnational Nurturing Nexus', Signs: Journal of Women in Culture and Society, 43 (1), 53-75.

Bojarczuk, S. and P. Mühlau (2018) 'Mobilising social network support for childcare: The case of Polish migrant mothers in Dublin', Social Networks 53, 101-110.

Bryceson, D. and U. Vuorela (eds.) (2002) The transnational family: new European frontiers and global networks, Oxford: Berg.

Buchowski, M. (1996) 'The shifting meanings of civil and civic society in Poland' in Dunn E. and C. Hann (Eds.), Civil society: challenging western models, London: Routledge, 79-98.

Burawoy, M. and K. Verdery (1999) Uncertain transition: ethnographies of change in the postsocialist world, Rowman \& Littlefield. 
Burrell, K. (2008) 'Managing, learning and sending: the material lives and journeys of Polish Women in Britain', Journal of Material Culture, 13 (1), 63-83.

Butt, L. (2018) 'Introduction: the absent child and transnational families', Global Networks 18 ( 1), 127-132.

Carsten, J. (2004) After kinship, Cambridge: Cambridge University Press.

Ciesek, B. (2017) ‘Przeciw wykluczeniu. Konceptualizacje współczesnej polskiej kobiety z perspektywy dyskursu feministycznego', Acta Universitatis Lodziensis Folia Linguistica, 51 (1), 11-28.

Cervinkova H., M. Buchowski and Z. Uherek (eds) (2015) Rethinking ethnography in Central Europe, New York: Palgrave Macmillan.

Cerwonka, A. and L.H. Malkki (2007) Improvising theory: Process and temporality in ethnographic fieldwork, Chicago: University of Chicago Press.

Chari, S. and K. Verdery (2009) 'Thinking between the posts: postcolonialism, postsocialism, and ethnography after the Cold War', Comparative Studies in Society and History, 51 (1), 6-34.

Deneva, N. (2012) 'Transnational Aging Carers: On Transformation of Kinship and Citizenship in the Context of Migration among Bulgarian Muslims in Spain', Social Politics, 19 (1), 105-128.

Ducu, V. (2014) 'Transnational mothers from Romania', Romanian Journal of Population Studies, 8 (1), 117-141.

Ducu, V., Nedelcu, M. and Telegdi-Csetri, A. (eds) (2018) Childhood and Parenting in Transnational Settings, Cham: Springer.

Fan, Y.K. and Parreñas, R. S. (2018) 'Who cares for the children and the elderly? Gender and transnational families', in Ducu, V., Nedelcu, M. and Telegdi-Csetri, A. (eds) Childhood and Parenting in Transnational Settings, Cham: Springer, 83-99.

Fidelis, M. (2010) Women, communism, and industrialization in postwar Poland, New York: Cambridge University Press.

Gal, S. and G. Kligman (2000) The politics of gender after socialism: a comparative-historical essay, Princeton, New Jersey: Princeton University Press.

Graff, Agnieszka (2014), 'Report from the gender trenches: War against 'genderism' in Poland', European Journal of Women's Studies, 21(4), 431-442.

Hann, C. M. (ed.) (2002) Postsocialism: ideals, ideologies, and practices in Eurasia, London and New York, Routledge. 
Hannerz, U. (1996) Transnational connections: culture, people, places. London: Routledge.

Hannerz, U. (2010) Anthropology's world: life in a twenty-first century, London, GBR: Pluto Press.

Hiitola, J. (2015) Halittu vanhemmuus. Sukupuoli, luokka ja etnisyys houstaanottoasiakirjoissa, Tampere: Tampereen yliopisto.

Huttunen, L. (2009) 'Historical legacies and neo-colonial forms of power?: a postcolonial reading of the Bosnian Diaspora', in S. Irni, S. Keskinen, D. Mulinari and Tuori S. (eds), Complying with colonialism. gender, 'race' and ethnic, Aldershot: Ashgate, 130-149.

Jansen, Stef (2015) Yearning in the meantime: "normal lives" and the state in the Sarajevo apartment complex. Oxford: Berghahn

Jokinen, E., J. Könönen, J. Venäläinenand J. Vähämäki (eds) (2011) "Yrittäkää edes!" Prekarisaatio Pohjois-Karjalassa, Helsinki: Titkijaliitto.

Jallinoja, R. and E. Widmer (2011) Families and kinship in contemporary Europe: rules and practices of relatedness, Palgrave Macmillan.

Kananen, J. (2016) 'The Nordic Welfare State in Three Eras From Emancipation to Discipline', Routledge: New York.

Kay, R. (2007) Gender, equality and difference during and after state socialism, New York: Palgrave Macmillan.

Keough, L. (2006) 'Globalizing 'postsocialism:' mobile mothers and neoliberalism on the margins of Europe', Anthropological Quarterly, 79 (3), 431-461.

Kettunen, P. (2006) 'The power of international comparison - a perspective on the making and challenging of the Nordic welfare state', in N. F. Christiansen, K. Petersen, N. Edling and P. Haave (eds) The Nordic Model of Welfare: a historical reappraisal., Museum Tusculanum Press.

Kideckel, D. (2014) 'Post-socialism as Uncertainty, Uncertainty about Post-socialism', in Ch. Giordano, F. Ruegg, A. Boscoboinik (eds) Does East go West? Anthropological Pathways through postsocialism, Münster: LIT, 15-26.

Kilkey M. and L. Merla (2014) 'Situating transnational families' care-giving arrangements: the role of institutional contexts', Global Networks, 14 (2), 210-229.

King, R. and J. Vullnetari (2009) 'The intersections of gender and generation in Albanian migration, remittances and transnational care', Geografiska Annaler: Series B, Human Geography 91(1), 19-38. 
Krasnova, O. (2000) 'Babushki v sem'e', Sotsiologicheskie issledovaniya, (11), 108-116.

Kravchenko, Z., J. Gradskova, J. and H. Carlbäck (2012) And they lived happily ever after: norms and everyday practices of family and parenthood in Russia and Central Europe, Budapest - New York: Central European University Press.

Lonkila, M. and A.M. Salmi (2005) 'The Russian Work Collective and Migration', Europe-Asia Studies, 57(5), 681-703.

Lähteenmäki, M. (1999) 'Responsibility Fosters Independence', in Women in Finland (H. Hawkins, Trans., pp. 39-54). Helsinki: Otava.

Marcus, G. E. (1995) 'Ethnography in/of the world system: the emergence of multi-sited ethnography', Annual Review of Anthropology, 24, 95-117.

Mędrzecki, W. (2003) 'Chłopi’, in W. Mędrzecki, S. Rudnicki and J. Żarnowski (eds) Społeczeństwo polskie w XX wieku, Warszawa: Instytut Historii PAN, 107-169.

Meagher, G. and Szebehely, M. (2012) 'Equality in the social service state: Nordic childcare models in comparative perspective', in J.Kvist, J. Fritzell, B. Hvinden and O. Kangas (eds) Changing Social Inequality: The Nordic welfare model in the 21st century, Bristol: Policy Press, 89-118.

Nedelcu, M. (2017) 'Transnational grandparenting in the digital age: mediated co-presence and childcare in the case of Romanian migrants in Switzerland and Canada', European Journal of Ageing, 14, 375-383.

Nedelcu, M. and M. Wyss (2016) "'Doing family" through ICT-mediated ordinary co- presence: transnational communication practices of Romanian migrants in Switzerland', Global Networks, $16(2), 202-218$.

Nesteruk, O. and L. Marks (2009) 'Grandparents across ocean: Eastern European immigrants' struggle to maintain intergenerational relationships', Journal of Comparative Family Studies, 40 (1), 7795.

Novikova, I. (2005) 'Riian "Mummokerhot". Ikä ja valta venäjänkielisessä translokaalissa ympäristössä', in Hirsiaho, A., Korpela, M. and L. Rantalaiho (eds) Kohtaamisia rajoilla, Tampere: Suomalaisen Kirjallisuuden Seura, 71-91.

Nowak, S. (1979) 'System wartości społeczeństwa polskiego’, Studia Socjologiczne, 4 (75), 155-173. Pajnik, M. and Bajt, V. (2012) 'Migrant Women's Transnationalism: Family Patterns and Policies', International Migration 50 (5), 153-168. 
Parreñas, R. S. (2001) Servants of globalization: women, migration, and domestic work, Stanford: Stanford University Press.

Plaza, D (2000) 'Transnational grannies: the changing family responsibilities of elderly African Caribbean-born women resident in Britain', Soc Indic Res, 51(1): 75-105.

Pöllänen, P. (2013) Hoivan rajat: venäläiset maahanmuuttajanaiset ja ylirajainen perhehoiva (Vol. Väestöntutkimuslaitoksen julkaisusarja D 57/2013.), Helsinki: Väestöliitto.

Reid, S. E. (2014) 'Makeshift Modernity. DIY, Craft and the Virtuous Homemaker in New Soviet Housing of the 1960s', International Journal for History, Culture and Modernity, 2(2) : 87-124.

Ries, N. (1997) Russian talk: culture and conversation during perestroika, NY: Cornell University Press.

Robila M. (2004) 'Families in Eastern Europe: Context, trends and variations', in Robila M. (ed) Families in Eastern Europe, Elsevier, 1-14.

Ryan, L. (2011) 'Transnational relations: family migration among recent Polish migrants in London', International Migration, 49 (2), 80-103.

Salazar, N. B. (2017) 'Key figures of mobility: an introduction', Social Anthropology, 25 (1), 5-12.

Simic, A. (1983) 'Machismo and Cryptomatriarchy: Power, Affect, and Authority in the Contemprorary Yugoslav Family', Ethos, 11(1/2), 66-86.

Skrbiš, Z. (2008) 'Transnational families: theorising migration, emotions and belonging', Journal of Intercultural Studies, 29 (3), 231-246.

Slany, K. (2002) Alternatywne formy życia matżensko-rodzinnego w ponowoczesnym świecie, Krakow: Nomos.

Solari, C. (2010) 'Resourse drain vs. constitutive circularity: comparing the gendered effects of postSoviet migration patterns in Ukraine', Anthropology of East Europe Review, (28), 215-238.

Sotkasiira, T. (2017) "'Sometimes It Feels Like Every Word is a Lie": Media Use and Social (In)Security among Finnish Russian-Speakers', Central and Eastern European Migration Review: 1-19.

Stanisz, A. (2013) Rodzina made in Poland: antropologia pokrewieństwa i życia rodzinnego, Poznań: Nauka i Innowacje.

Szlagowska, A. (2016) 'Modele macierzyństwa i kontrola urodzeń w PRL-u’, Pamięć i Przyszłość 1(31), 6-19. 
Tiaynen, T. (2013) Babushka in Flux: Grandmothers and Family-making between Russian Karelia and Finland, Tampere: Tampere University Press.

Tiaynen-Qadir, T. (2016) 'Transnational Babushka: Grandmothers and Family-making between Russian Karelia and Finland', in V. Horn and C. Schweppe (eds) Transnational Aging: Current Insights and Future Challenges, New York \& Abingdon, Routledge, 85-104.

Tulbure, N. (2009) 'Introduction to Special Issue: Global Socialisms and Postsocialisms', Anthropology of East Europe Review, 27 (2), 2-18.

Uspenskaya VI. and D. Borodin (2004) 'Family relations in 20th century Russia as a projection of popular beliefs, scholarly discourse and state policies', in Robila M. (ed) Families in Eastern Europe, Elsevier, 237-248.

Utrata, J. (2015) Women without men. Single mothers and family change in the new Russia, Ithaca and London: Cornell University Press.

Vered, A.-T. (ed) (2000) Constructing Field: Ethnographic Fieldwork in Contemporary World, London: Routledge.

Verdery, K. (1998) 'Transnationalism, nationalism, citizenship, and property: Eastern Europe since 1989', American Ethnologist, 25(2), 291-306.

Vertovec, S. (2009) Transnationalism, London: Routledge.

Vullnetari J. and R. King (2014) 'Women Here Are Like at the Time of Enver [Hoxha]': Socialist and Post-Socialist Gendered Mobilities in Albanian Society', in K. Burrell and K. Hörschelmann (eds) Mobilities in Socialist and Post-Socialist States: Societies on the Move, Basingstoke and New York, NY: Palgrave Macmillan, 122-147.

Vuorela, U. (2002). 'Transnational Families: Imagined and Real Communities' in D. Bryceson and U. Vuorela (eds), The Transnational Family. New European Frontiers and Global Networks, Oxford: Berg, 63-82.

Walsh, K. and L. Näre (eds) (2016) Transnational migration and home in older age, London \& New York: Routledge.

Wedel, J. R. (1986) The private Poland: an anthropologist's look at everyday life, New York: Facts on File.

Yeoh, B. and K. Ramdas (2014) 'Gender, migration, mobility and transnationalism', Gender, Place \& Culture, 21 (10): 1197-1213. 
Yurchak, A. (2006) Everything Was Forever, Until It Was No More: The Last Soviet Generation, Princeton: Princeton University Press.

Zdravomyslova, E., A. Rotkirch, and A. A. Temkina (eds.) 2009 Novyi byt v sovremennoi Rossii: gendernye issledovaniya povsednevnosti, St. Petersburg: EUSPb.

Zechner, M. (2010) Informaali hoiva sociaalipoliittisessa kontekstissa, Tampere: Acta Universitalis Tamperensis.

Zontini E. (2011) Transnational families, migration and gender: Moroccan and Filipino women in Bologna and Barcelona, New York, Oxford: Berghahn. 